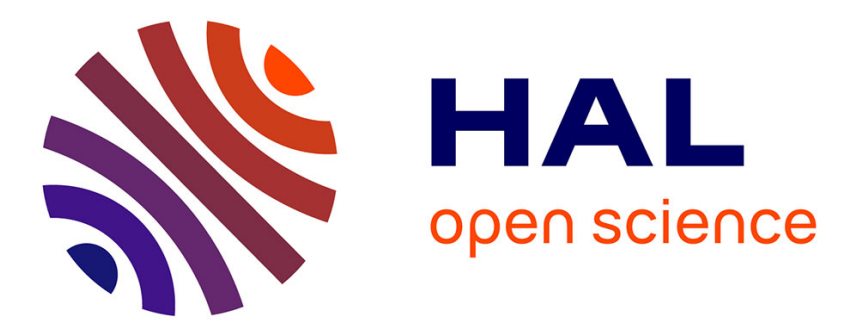

\title{
Optimization of the Microporous Layer for a Polybenzimidazole-based High Temperature PEMFC. Effect of carbon content
}

Justo Lobato, Pablo Cañizares, Manuel A Rodrigo, Diego Ubeda, Francisco J Pinar, Jose J Linares

\section{To cite this version:}

Justo Lobato, Pablo Cañizares, Manuel A Rodrigo, Diego Ubeda, Francisco J Pinar, et al.. Optimization of the Microporous Layer for a Polybenzimidazole-based High Temperature PEMFC. Effect of carbon content. Fuel Cells, 2010, 10 (5), pp.770. 10.1002/fuce.200900175 . hal-00578450

\author{
HAL Id: hal-00578450 \\ https://hal.science/hal-00578450
}

Submitted on 21 Mar 2011

HAL is a multi-disciplinary open access archive for the deposit and dissemination of scientific research documents, whether they are published or not. The documents may come from teaching and research institutions in France or abroad, or from public or private research centers.
L'archive ouverte pluridisciplinaire HAL, est destinée au dépôt et à la diffusion de documents scientifiques de niveau recherche, publiés ou non, émanant des établissements d'enseignement et de recherche français ou étrangers, des laboratoires publics ou privés. 


\section{Optimization of the Microporous Layer for a Polybenzimidazole-based High Temperature PEMFC. Effect of carbon content}

\begin{tabular}{|r|l|}
\hline Journal: & Fuel Cells \\
\hline Manuscript ID: & fuce.200900175.R1 \\
\hline Wiley - Manuscript type: & Original Research Paper \\
\hline Date Submitted by the & O3-Dec-2009 \\
\hline Complete List of Authors: & $\begin{array}{l}\text { LOBATO, JUSTO; University of Castilla-La Mancha, Chemical } \\
\text { Engineering Department } \\
\text { Cañizares, Pablo; University of Castilla-La Mancha, Chemical } \\
\text { Engineering } \\
\text { Rodrigo, Manuel; University of Castilla-La Mancha, Chemical } \\
\text { Engineering } \\
\text { Ubeda, Diego; University of Castilla-La Mancha, Chemical } \\
\text { Engineering } \\
\text { Pinar, Francisco; University of Castilla-La Mancha, Chemical } \\
\text { Engineering } \\
\text { Linares, Jose; University of Castilla-La Mancha, Chemical } \\
\text { Engineering }\end{array}$ \\
\hline Keywords: & $\begin{array}{l}\text { Carbon, High Temperature, ESA, Performance, PBI, Microporus } \\
\text { Layer }\end{array}$ \\
\hline \hline
\end{tabular}

\section{S) ScholaroNE \\ Manuscript Central}




\title{
Optimization of the Microporous Layer for a Polybenzimidazole-based High
} Temperature PEMFC. Effect of carbon content.

\author{
Justo Lobato*, Pablo Cañizares, Manuel A, Rodrigo, Diego Úbeda, F. Javier. Pinar and
} José J. Linares.

Chemical Engineering Department, University of Castilla-La Mancha, Av. Camilo Jose Cela, n 12. 13071, Ciudad Real (Spain).

* Corresponding author: Phone: +34 926295300 Ext. 3418. Fax: +34 926295256. Email: Justo.Lobato@uclm.es

\section{ABSTRACT}

This work aims at studying the role of the microporous layer (MPL) in electrodes prepared for High Temperature PBI-based PEMFC. The two main components of this layer are carbon black and a polymeric binder (Teflon). This work addresses the effect of the MPL carbon amount on the performance of a High Temperature PEMFC. Thus, gas diffusion layers (GDL) containing MPL with different carbon contents (from 0.5 to $4 \mathrm{mg} \mathrm{cm}^{-2}$ ) were prepared. Firstly, they were physically characterized by $\mathrm{Hg}$ Porosimetry measuring pore size distribution, porosity, tortuosity and mean pore size. Permeability measurements were also performed. The higher the carbon content was the lower both porosity and permeability were. Afterwards, electrodes were prepared with these GDL $\underline{s}$ and were electrochemically characterized. Electrochemical surface area (ESA) was determined and fuel cell performance was evaluated under different fuel and comburent stoichiometries, supporting these results with impedance spectra. This made possible to see the benefits of the MPL inclusion in the electrode structure, with a significant increase in the fuel cell performance and ESA. Once the goodness of the 
MPL was confirmed, result analysis led to an optimum MPL composition of $2 \mathrm{mg} \mathrm{cm}^{-2}$ of carbon for both electrodes, anode and cathode.

Keywords: Carbon, ESA, High temperature, Microporous layer, PBI, Performance.

\section{Introduction}


During recent years, extensive research activities have been made on high temperature proton exchange membrane fuel cells (HT-PEMFCs) because of the numerous advantages that this technology shows, which can be found elsewhere [1-3]. Working at high temperatures, above $100{ }^{\circ} \mathrm{C}$, requires new materials for membranes different to the traditional Nafion or similar polymers. Among the different possibilities, polybenzimidazol (PBI)-based membranes are one on the most important and seem to be the most suitable for both automobile and stationary applications [4].

The membrane-electrode assembly (MEA) is the main part of PEMFCs. It consists of a proton exchange membrane located between two catalyst layers and a gas diffusion layer (GDL) backing each one. The most important function of the GDL is to distribute the reactant gases over the catalyst layer and to remove the generated products out of the fuel cell $[5,6]$. More information about the characteristics and manufacturing processes of GDLs can be found in an interesting review by Cindrella et al. [7]. With the aim of improving water management in PEMFCs, GDLs have been impregnated with a hydrophobic polymer and a micro-porous layer (MPL) has been added on one side of the GDL [8]. Ramasamy et al. have demonstrated mass transfer improvement when these treatments are applied, in terms of both increasing limiting current as well as reducing mass transfer resistance [9]. MPL characteristics depend on the carbon type, the polymeric adhesive used, the solvent used to prepare the solution and on the composition. Moreover, the deposition techniques and the solvent evaporation rates have an important role on the final MPL properties [7, 10,11]. Once the MPL is deposited, the sintering process is an important step. The objective of this method is the right distribution of the polymeric adhesive over the entire surface and the removal of some remaining solvent [12]. 
In this work, GDLs containing MPL with different carbon contents were prepared to be used in a high temperature PEMFC operating above $100^{\circ} \mathrm{C}$. In order to optimize the amount of carbon in the MPL, the GDLs were physically characterised and the electrodes prepared with those GDLs were electrochemically characterised in a single fuel cell.

\section{Experimental}

Black carbon Vulcan XC72-R and PTFE were used as carbon material and polymeric adhesive, respectively. Isopropyl alcohol was the solvent used to prepare the ink that was deposited by air spraying onto the commercial GDL (Toray Graphite paper TGPH120. $0.35 \mathrm{~mm}$ ) with a Teflon content of $10 \%$, chosen from a previous work [6].

The Teflon content in the MPL was also $10 \%$ [13] and the carbon amount was in the range $0.5-4.0 \mathrm{mg} \mathrm{cm}^{-2}$.

\subsection{Physical characterisation of the gas diffusion media}

Mercury porosimetry was used to determine the porosity of the samples. This also enabled the evaluation of pore size distribution. The equipment used for the determination was a Micromeritics Auto Pore IV 9500 Hg porometer.

Permeability was determined by using Darcy's law $[6,10.13]$. Permeability coefficient $\left(\mathrm{k}, \mathrm{m}^{2}\right)$ can be calculated by using the following expression:

$$
k=v \cdot \mu \cdot \frac{l}{\Delta P}
$$


where $v$ is the air flux $\left(\mathrm{m} \mathrm{s}^{-1}\right), \mu$ is the air viscosity $(\mathrm{Pa} \mathrm{s}), 1$ is the thickness of the sample $(\mathrm{m})$, and $\Delta \mathrm{P}$ is the pressure drop across the substrate $(\mathrm{Pa})$.

Permeability was evaluated with a home-made apparatus that was designed and made in-house. In this set up, air is forced to flow through the GDM and pressure drop is measured with a water column. Circular-shaped samples of $10 \mathrm{~cm}$ diameter were utilized for the measurements [13].

\subsection{Fuel cell measurements}

The preparation of a membrane-electrode-assembly (MEA) can be briefly described as follows. On top of each gas diffusion media, the catalytic layer formed by $0.5 \mathrm{mg} / \mathrm{cm}^{2}$ of platinum from 20\% Pt on Vulcan XC-72R carbon black (ETEK-Inc, USA) and 0.5 $\mathrm{mg} / \mathrm{cm}^{2} \mathrm{PBI}$ (from a 5\% PBI solution in N,N'-dimethylacetamide) was deposited with an aerograph $\left(\mathrm{N}_{2}\right.$ as carrier gas). The gas diffusion electrodes were then cured in an oven for 2 hours at $190{ }^{\circ} \mathrm{C}$ and soaked with a $10 \%$ wt. $\mathrm{H}_{3} \mathrm{PO}_{4}$ solution until a load of 30 $\mathrm{mg} \cdot \mathrm{cm}^{-2}$ was obtained, leaving them for at least 4 days in order to achieve complete impregnation. Polybenzimidazole membranes, produced according to the procedure described elsewhere [14,15], were immersed in an $80 \% \mathrm{H}_{3} \mathrm{PO}_{4}$ bath (doping level of 6.7) and then removed and blotted with filter paper to remove the superficial acid. Hotpressing to obtain the MEA was carried out by placing the membrane between the electrodes. A load of 1 tonne (minimum applicable using our equipment) was subsequently applied at $130{ }^{\circ} \mathrm{C}$ for 15 minutes. A press for the preparation of IR pellets (Graseby Specac, United Kingdom) was modified and adapted for the membrane- 
electrode assembly process. The active area of the electrodes was $4.65 \mathrm{~cm}^{2}$. Tests were carried out using the same gas diffusion layers in both anode and cathode, i.e., each MEA (pair of electrodes) had the same Teflon content, $10 \%$.

Measurements were taken using an Autolab PGSTAT 30 Potentiostat/Galvanostat equipped with a Current Booster (20 A). The cell was firstly conditioned at a fixed potential of $0.5 \mathrm{~V}$ and $125^{\circ} \mathrm{C}$ for 24 hours, with the system attaining a steady current after several hours, as reported elsewhere [16,17]. Once this period had elapsed, polarization curves were recorded in a potentio-dynamic polarization mode [6]. The potential was swept between the cell open circuit voltage and $0 \mathrm{~V}$ at $1 \mathrm{mV} \mathrm{s}^{-1}$. The cell was always operated at $125^{\circ} \mathrm{C}$ and atmospheric pressure. Hydrogen $(99.999 \%$ pure, Praxair, Spain) was fed into the cell at a flow rate of $200 \mathrm{ml} / \mathrm{min}$, whereas oxygen (99.999\% pure, Praxair, Spain) was fed.

Measurement of the electrochemical surface area (ESA) of the electrodes was carried out by cyclic voltammetry $(\mathrm{CV})$ running $\mathrm{N}_{2}(200 \mathrm{ml} / \mathrm{min})$ through the cathode and $\mathrm{H}_{2}$ $(134 \mathrm{ml} / \mathrm{min})$ through the anode at room temperature with a potential range from $0 \mathrm{~V}$ approx. to $1.4 \mathrm{~V}$ approx. versus standard hydrogen electrode (SHE) and a sweep rate of $20 \mathrm{mV} / \mathrm{s}$. The electrochemical impedance spectra were recorded using the frequency response analysis (FRA) module of the potentiostat/galvanostat at a potential of $0.3 \mathrm{~V}$. Frequency ranged from $10 \mathrm{KHz}$ down to $10 \mathrm{mHz}$, with a potential wave of $0.01 \mathrm{~V}$.

\section{Results and discussion}

3.1 Porosity and Pore size distribution 
Figure 1 shows pore size distributions of the GDL with different carbon loads in MPLs and, solely to compare, with no MPL. Two ranges of the specific pore volume are shown in this figure; Figure 1a shows the macropores and Figure $1 \mathrm{~b}$ the micro and mesopores region. It can be observed that the deposition of a MPL in the electrode structure leads to a decrease in the number of macropores of the gas diffusion layers. Moreover, the carbon amount is higher the lower is the macroporosity until a value of 2 $\mathrm{mg}$ carbon $\mathrm{cm}^{2}$ is reached. From this value, the macroporosity does not decrease, which means that no more carbon particles are introduced into the gas diffusion layer. Respecting the meso and micro pores region, it can be said that as the carbon content increases, the meso and micropores generated are higher, which leads to a porosity increase in this range of pore sizes [18].

Figure 1

From pore size distribution data, porosity, tortuosity and mean pore diameter can be estimated. Figure 2 shows those parameters versus carbon content. It can be seen that the overall porosity decreases with the carbon deposited on the microporous layer. This can be due to the decrease of the macroporosity of the carbon support when the microporous layer is deposited and then introduced into the carbon support of the gas diffusion. On the other hand, it can be due to the microporous layer intrinsic microporosity, which leads to a decrease of the overall porosity. The same comment can be made for the case of mean pore diameter. The microporous layer carbon can block part of the macropores of the gas diffusion layer, leading to a decrease in the pore size. However, at carbon load values higher than $2 \mathrm{mg} \mathrm{cm}^{-2}$ the decrease in the pore size is lower. With respect to tortuosity, it can be observed that this parameter increases linearly with the carbon content of the microporous layer. This effect was the expected 
since as the carbon amount increases, its thickness is higher and the gas flow through that layer is then more difficult.

Figure 2 .

\subsection{Gas and water vapour permeability}

The variation of permeability of the different gases present in a fuel cell $\left(\mathrm{H}_{2}, \mathrm{O}_{2}\right.$ and air), as well as water vapour with respect to the carbon content of the MPL is shown in Figure 3. It must be remarked that in the experimental system, water produced in the cathode will be in vapour state because it operates at temperature above $100{ }^{\circ} \mathrm{C}$.

Moreover, the corresponding value of the GDL is also shown. In all cases, it can be seen that the deposition of a thicker microporous layer (higher carbon content) leads to a permeability decrease. As it was observed in the previous figures, the microporosity increase and the macroporosity decrease hinder the gas flow through the electrode and hence from the mass transfer point of view, the deposition of a microporous layer would not be beneficial.

Figure 3.

\subsection{Cyclic voltammetry}

Figure 4 shows the cyclic voltammograms of the electrodes prepared with MPL with different carbon contents. In figure $4 \mathrm{~b}$ the values of the electrochemical surface area (ESA) calculated from the voltammograms are shown. They were given by the following formula:

$$
E S A=\frac{A_{P_{t}}}{v C} \frac{1}{L_{e}}
$$

Where $\mathrm{A}_{\mathrm{Pt}}\left(\mathrm{A} \cdot \mathrm{V} / \mathrm{cm}^{2}\right)$ is the area under the hydrogen desorption peak obtained by $\mathrm{CV}$ measurements, $v(\mathrm{~V} / \mathrm{s})$ is the sweep rate, $20 \mathrm{mV} / \mathrm{s}, \mathrm{C}$ represents the charge required to 


\section{Figure 4.}

\subsection{Fuel cell test. Cathode performance}

In order to evaluate cathode performance, a set of experiments at $125^{\circ} \mathrm{C}$ was carried out using cathodes with different carbon content in the MPL. In the anode, carbon content was in all cases equal to $1 \mathrm{mgcm}^{-2}$. To evaluate the effect of the different carbon content on the fuel cell performance oxygen stoichiometry was changed from 4 to 1.5 . An air

Deleted: Moreover, it is seen that the available area of Pt sites reaches its maximum value at $2 \mathrm{mg}$ carbon $\mathrm{cm}^{-2}$, approx. Further increase beyond this value does not increase the electrochemical surface area. It seems that at $2 \mathrm{mg} \mathrm{cm}^{-2}$ the microporous layer performs its role in protecting the catalyst layer making the catalyst sites more accessible to the reactants. 
flow was also used (oxygen stoichiometry equals to 4). Figure 5 shows the corresponding polarisation curves. In all cases it can be observed that the deposition of a thicker MPL leads to a performance increase up to a carbon amount of $2 \mathrm{mgcm}^{-2}$. The lower performance, independently of the comburent used, detected on the cell incorporating the electrode without the supporting layer, MPL, can be explained by the reduction of available catalyst sites [20] as it was observed previously by the cyclic voltammetry analysis.

\section{Figure 5.}

With the aim of obtaining more information about the fuel cell performance using cathodes containing MPL with different carbon contents, AC impedance spectroscopy was used to diagnose the fuel cell under the operation conditions above commented. Figure 6 shows the impedance spectra and Table 1 shows the values of the different parameters obtained from it and the equivalent circuit used in this work, which is the same to other used by Zhang et al. for a PBI-based high temperature PEMFC [21]. $\mathrm{R}_{\mathrm{o}}$ is the high-frequency resistance which represents the ohmic resistance of the fuel cell that is dominated by the membrane resistance. $R_{c t}$ is the charge transfer resistance related to the fuel cell reaction kinetics, contributed by both the cathodic ORR and anodic HOR processes. Finally, $\mathrm{R}_{\mathrm{mt}}$ is the resistance related to mass transfer processes, contributed by the diffusion of $\mathrm{H}_{2}$ and $\mathrm{O}_{2}$ to catalyst sites and the proton transfer resistance within the catalyst layers [21].

\section{Figure 6}

Table 1

AC impedance analysis also confirms the existence of an optimal MPL carbon amount in the cathode electrode for all oxygen stoichiometries studied as well as the beneficial 
1

2

3

4

5

6

7

8

9

10

use of a MPL. From Figures 5, 6 and values from Table 1 it can be better noticed the effect of the microporous layer carbon content on the fuel cell performance. In the activation polarization region (low current densities) it can be observed that the presence of a thicker MPL is beneficial because the active surface area increases with the thickness of the MPL till a value of carbon content of $2 \mathrm{mg} \mathrm{cm}^{-2}$. From this value on, there is not any performance increase in this polarization curve region and the $\mathrm{R}_{\mathrm{ct}}$ values are very similar from that point. On the other hand, the $\mathrm{R}_{\mathrm{mt}}$ values are higher when the $\mathrm{O}_{2}$ stoichiometry decreases or when air is used as comburent. The effect of carbon load is more noticeable in these poor oxygen available conditions, where any improvement of the catalytic activity will have a big repercussion on the oxygen reduction reaction. Under these conditions, the $R_{\mathrm{ct}}$ values for the GDL with $4 \mathrm{mg} \mathrm{cm}^{-2}$ of carbon increase with respect to those of the $2 \mathrm{mg} \mathrm{cm}^{-2}$.

Regarding the ohmic resistance, it can be observed that the slope of the polarisation curves and the Ro values decrease again until the carbon content value of $2 \mathrm{mg} \mathrm{cm}^{-2}$ is reached. A good distribution of the different layers, carbon support (GDL), microporous layer (MPL), and catalyst layer allow to reduce the fuel cell ohmic polarisation and to improve the transit of reactant or product gases. Even the improvement of the catalyst activity could help to decrease $R_{o}[22,23]$. Another factor that is helpful to decrease the Ro is the membrane hydration, which improves the membrane conductivity. A different level of membrane hydration could be occurring with the different MPL prepared; without MPL, ohmic resistance is higher than with MPL due to a MPL could retain water, which increases the conduction mechanism. Higher $\mathrm{R}_{\mathrm{o}}$ values when using a carbon load of $4 \mathrm{mg} \mathrm{cm}^{-2}$ can be consequence of a thicker MPL than the resulting when 


\begin{abstract}
using $2 \mathrm{mg} \mathrm{cm}^{-2}$, as well as the lower performance of this assembly which further reduces the level of hydration of this membrane.
\end{abstract}

Finally, the same comments stated above can be valid for the case of the concentration polarization (high current densities). The $\mathrm{R}_{\mathrm{mt}}$ values decrease as the carbon content increases till a value of $2 \mathrm{mgcm}^{-2}$. Higher carbon contents are not recommended because of some diffusion problems through the thicker layer. Moreover, it can be noticed that the decrease of the $\mathrm{O}_{2}$ availability affects mainly to the mass transfer properties. Thus, the $\mathrm{R}_{\mathrm{mt}}$ variations are higher when a low $\mathrm{O}_{2}$ stoichiometry or air as comburent is used.

\title{
3.5 Fuel cell test. Anode performance
}

In this case, fuel cell performance was studied changing the MPL carbon content of the anodes. Two different $\mathrm{H}_{2}$ stoichiometries were selected ( 1 and 4 for $1 \mathrm{Acm}^{-2}$ ). Figure 7 shows the polarisation curves. The same trends can be observed than those for the cathode study. There is an optimum level of carbon in the MPL which corresponds to the value of $2 \mathrm{mgcm}^{-2}$. Nevertheless in this case, the differences are not so high because the electrode that actually controls fuel cell performance is the cathode.

\section{Figure 7}

\section{Conclusions}

In this work, the effect of the MPL carbon content on the PBI-based High temperature PEM fuel cell performance has been studied. From this study the following conclusion can be drawn: 
The presence of a MPL is beneficial for the HT-PEMFC, as it improves the adhesion of the electrode different layers and increases the electrochemical area surface, increasing thus general fuel cell performance. The optimum carbon content was $2 \mathrm{mg} \mathrm{cm}^{-2}$ under this work operation conditions. With this carbon load the different resistances (activation, ohmic and concentration) are lower and then it leads to an electrode with the best characteristics for the catalytic and mass transfer processes.

\section{Acknowledgments}

The authors want to thank the Ministry of Education and Science of the Spanish Government, the Junta de Comunidades de Castilla-La Mancha and the enterprise CLM-H2 for the financial support through the projects CTM2007-60472 and PBI08151-2045, respectively. The Spanish Government (Ministerio de Ciencia e Innovación) is also thanked for the grant AP2007-02713 awarded to D. Úbeda.

\section{References}

[1] C. Yang, P. Costamagna, S. Srinivasan, J. Benziger, AB. Bocarsly, J. Power Sources, 2001, 103, 1.

[2] QF. Li, RH. He, JO. Jensen, NJ. Bjerrum, Chem. Mater. 2003, 15, 4896.

[3] YY. Shao, GP. Yin, ZB, Wang, YZ. Gao, J. Power Sources, 2007, 167, 235.

[4] QF. Li, JO. Jensen, RF. Savinell, NJ. Bjerrum, Prog. Poly. Sci., 2009, 34, 449.

[5] L. Carrette, KA. Friedrich, U. Stimming, Fuel Cells, 2001, 1, 5.

[6] J. Lobato, P. Cañizares, MA. Rodrigo, C. Ruiz-López, JJ. Linares, J. Appl.

Electrochem., 2008, 38, 793.

[7] L. Cindrella, AM. Kannan, JF. Lin, K. Saminathan, Y. Ho, CW. Lin, J. Wertz, J.

Power Sources, 2009, 194, 146. 
[8] JT. Gostick, A. Ioannidis, M.W. Fowler, MD, Pritzker, Electrochem. Comm., 2009, 11,576 .

[9] RP. Ramasamy, EC. Kumbur, MM. Mench, W. Liu, D. Moore, M. Murthy, Int. J. Hydrogen Energy, 2008, 33, 3351.

[10] M. Mathias, J. Roth, J. Fleming, W. Lehnert, Handbook of Fuel Cells, volume. 3, Chapter 46. (Eds W. Vielstich, A. Lamm, HA: Gasteiger). John Wiley \& Sons, 2003.

[11] W-M. Yan, C-Y. Hsueh, C-Y. Soong, F. Chen, C-H. Cheng, S-C. Mei, Int. J. Hydrogen Energy, 2007, 32, 4452.

[12] X. Cheng, B. Yi, M. Han, J. Zhang, Y. Qiao, J. Yu, J. Power Sources, 1999, 79, 75.

[13] JJ. Linares, Thesis. Univ. of Castilla-La Mancha, 2009.

[14] J. Lobato, P. Cañizares, MA. Rodrigo, JJ. Linares, G. Manjavacas, J. Membr. Sci., 2006, 280. 351 .

[15] J. Lobato, P. Cañizares, MA. Rodrigo, JJ. Linares, JA. Aguilar, J. Membr. Sci., 2007, 306, 47.

[16] J. Lobato, P. Cañizares, MA. Rodrigo, JJ. Linares, Electrochim. Acta, 2007, 52, 3910.

[17] J. Lobato, P. Cañizares, MA. Rodrigo, JJ. Linares, C. Piuleac, S. Corteanu, J. Power Sources, 2009, 192, 190.

[18] S. Park, J-W. Lee, BN. Popov, J. Power Sources, 2006, 163, 357.

[19] J. Lobato, P. Cañizares, MA. Rodrigo, JJ. Linares, D. Úbeda, FJ. Pinar, Fuel Cells, 2009, Accepted

[20] JM. Song, SY. Cha, WM. Lee, J. Power Sources, 2001, 94, 78.

[21] J. Zhang, Y. Tang, C. Song, J. Zhang, J. Power Sources, 2007, 172, 163.

[22] VA. Paganin, EA. Ticianelli, ER. Gonzalez, J. Appl. Electrochem., 1996, 26, 297.

[23] E. Antolini, R.R. Pasos, EA. Ticianelli, J. Appl. Electrochem. 2002, 32, 383. 


\section{CAPTION FOR FIGURES}

FIGURE 1. Specific pore size distribution of gas diffusion layers with different carbon loads in MPL. a) Macropore region; b) Meso and micropore region. Carbon load: (一) without MPL, (--) $0.5 \mathrm{mg} \mathrm{cm}^{-2}$, (-•) $1 \mathrm{mg} \mathrm{cm}^{-2}$, (-•-) $2 \mathrm{mg} \mathrm{cm}^{-2}$, (- -) $4 \mathrm{mg} \mathrm{cm}^{-2}$.

FIGURE 2. Parameters from Hg-porosimetry vs carbon load. a) Porosity; b) Mean pore diameter; c) Tortuosity.

FIGURE 3. Permeability measurements vs carbon content of the MPL. a) $\mathrm{H}_{2}$; b) $\mathrm{O}_{2}$; c) Air; d) water vapour

FIGURE 4. Cyclic voltammetry analysis. a) Cyclic voltammograms of the electrodes with different carbon contents in the MPL. Scan rate $20 \mathrm{mV} / \mathrm{s}$. b) Values of ESA vs carbon content in the MPL. (一) without MPL, (--) $0.5 \mathrm{mg} \mathrm{cm}^{-2},(-\cdot) 1 \mathrm{mg} \mathrm{cm}^{-2},(-\cdot-)$ $2 \mathrm{mg} \mathrm{cm}^{-2},(--) 4 \mathrm{mg} \mathrm{cm}^{-2}$.

FIGURE 5. Fuel cell performance with cathodes containing MPL with different carbon contents. a) $\mathrm{O}_{2}$ stoichiometry $=4$; b) $\mathrm{O}_{2}$ stoichiometry $=1.5$; c) Air flow $\left(\mathrm{O}_{2}\right.$ stoichometry $=4)$. Carbon contents: $(\square)$ without MPL, (O) $0.5 \mathrm{mg} \mathrm{cm}^{-2},(\triangle) 1 \mathrm{mg} \mathrm{cm}^{-}$ ${ }^{2},(\nabla) 2 \mathrm{mg} \mathrm{cm}^{-2},(\diamond) 4 \mathrm{mg} \mathrm{cm}^{-2}$.

FIGURE 6. Impedance spectra for the different gas diffusion layers. a) $\mathrm{O}_{2}$ stoichiometry equals 4 ; b) $\mathrm{O}_{2}$ stoichiometry equals 1.5 ; c) air. Carbon content in the 
MPL: $(\square)$ without MPL, (O) $0.5 \mathrm{mg} \mathrm{cm}^{-2},(\triangle) 1 \mathrm{mg} \mathrm{cm}^{-2},(\nabla) 2 \mathrm{mg} \mathrm{cm}^{-2},(\diamond) 4 \mathrm{mg}$ $\mathrm{cm}^{-2}$

FIGURE 7. Fuel cell performance with anodes containing MPL with different carbon contents. a) $\mathrm{H}_{2}$ stoichiometry $=4$; b) $\mathrm{H}_{2}$ stoichiometry $=1$. Carbon contents: $(\square)$ without MPL, (O) $0.5 \mathrm{mg} \mathrm{cm}^{-2},(\triangle) 1 \mathrm{mg} \mathrm{cm}^{-2},(\nabla) 2 \mathrm{mg} \mathrm{cm}^{-2},(\diamond) 4 \mathrm{mg} \mathrm{cm}^{-2}$. 
Table 1. Resistance values obtained from the Nyquist plot (Figure 6)

\begin{tabular}{|c|c|c|c|c|c|c|}
\hline \multicolumn{2}{|c|}{$\begin{array}{l}\text { Carbon content of MPL } \\
\mathrm{mg} \mathrm{cm}\end{array}$} & $\begin{array}{c}\text { Without } \\
\text { MPL }\end{array}$ & 0.5 & 1 & 2 & 4 \\
\hline \multirow{3}{*}{$\mathrm{O}_{2}$ Stoichio. 4} & $R_{o} / \mathrm{ohm} \mathrm{cm}^{2}$ & 0.154 & 0.125 & 0.108 & 0.103 & 0.106 \\
\hline & $R_{c t} / \mathrm{ohm} \mathrm{cm}^{2}$ & 0.057 & 0.054 & 0.050 & 0.047 & 0.046 \\
\hline & $R_{m t} / \mathrm{ohm} \mathrm{cm}$ & 0.164 & 0.131 & 0.115 & 0.110 & 0.122 \\
\hline \multirow{3}{*}{$\mathrm{O}_{2}$ Stoichio. 1.5} & $R_{o} / \mathrm{ohm} \mathrm{cm}$ & 0.155 & 0.131 & 0.112 & 0.104 & 0.108 \\
\hline & $R_{c t} / \mathrm{ohm} \mathrm{cm}^{2}$ & 0.061 & 0.058 & 0.053 & 0.049 & 0.050 \\
\hline & $R_{m t} / \mathrm{ohm} \mathrm{cm}$ & 0.256 & 0.221 & 0.189 & 0.169 & 0.195 \\
\hline \multirow{3}{*}{$\begin{array}{l}\text { Air }\left(4 \mathrm{O}_{2}\right. \\
\text { Stoichio. 4) }\end{array}$} & $R_{o} / \mathrm{ohm} \mathrm{cm} \mathrm{cm}^{2}$ & 0.160 & 0.142 & 0.118 & 0.111 & 0.116 \\
\hline & $R_{c t} / \mathrm{ohm} \mathbf{c m}^{2}$ & 0.129 & 0.118 & 0.102 & 0.095 & 0.097 \\
\hline & $R_{m t} / \mathrm{ohm} \mathrm{cm}$ & 0.744 & 0.621 & 0.430 & 0.408 & 0.565 \\
\hline
\end{tabular}



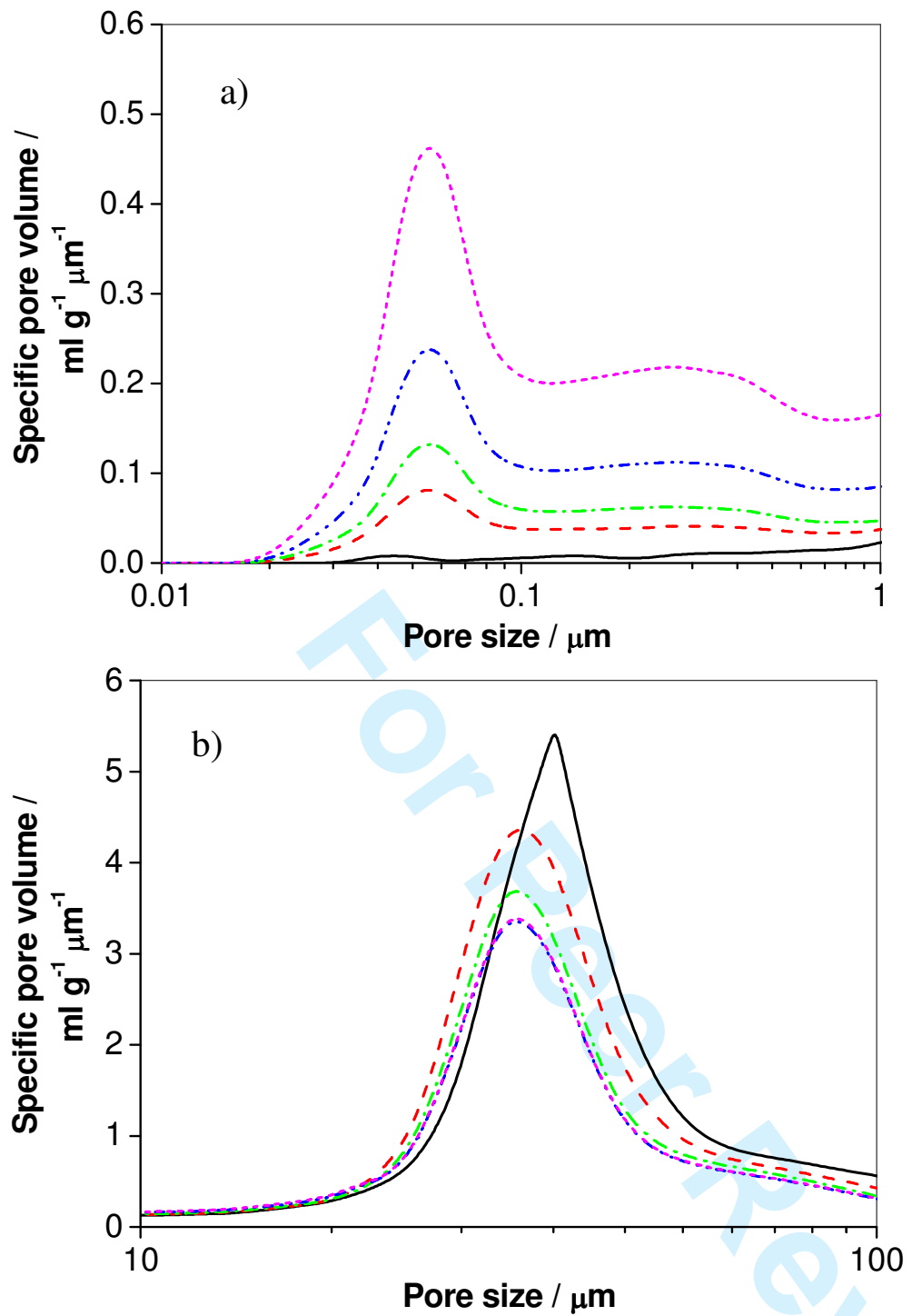

Figure 1 


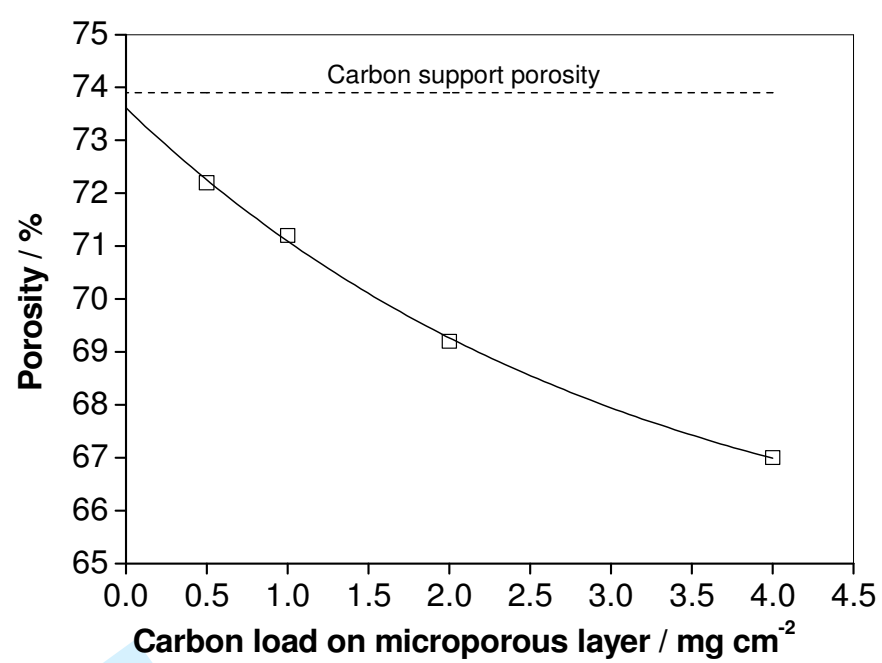

(a)

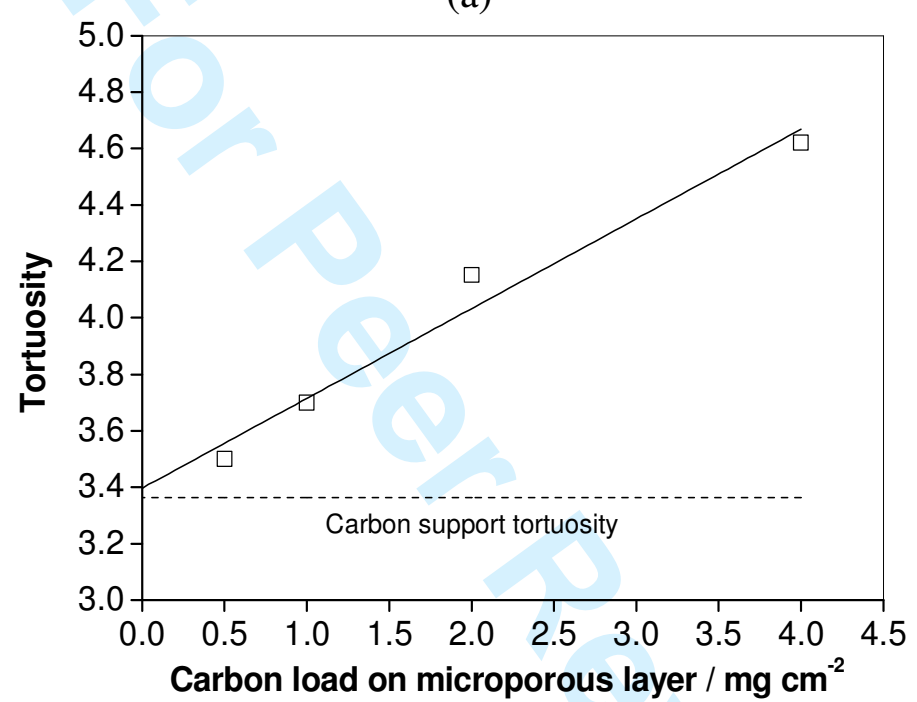

(b)

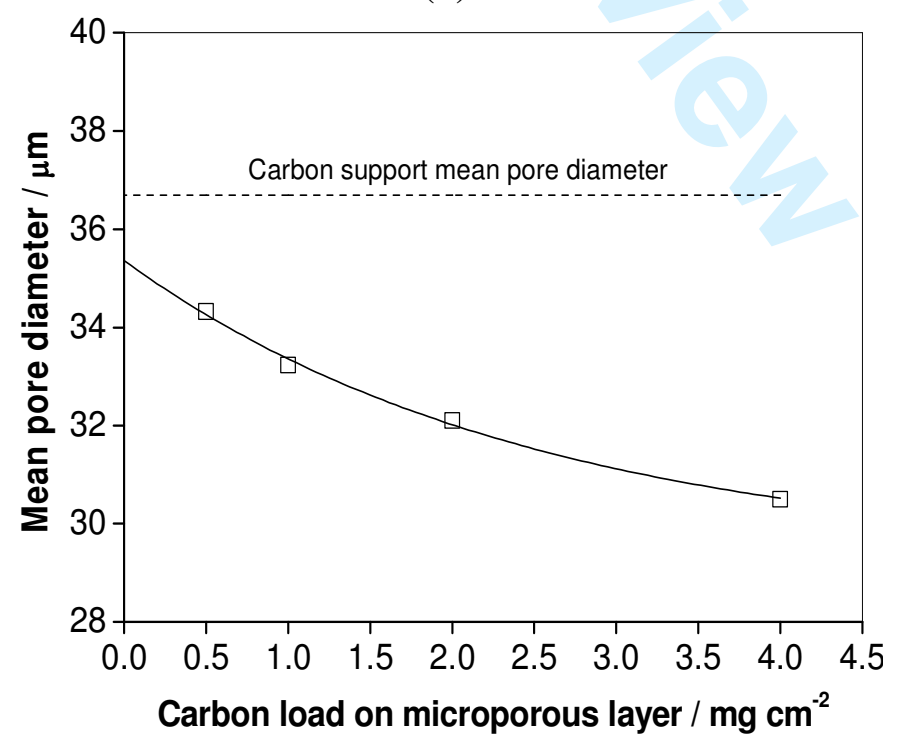

(c)

Figure 2 


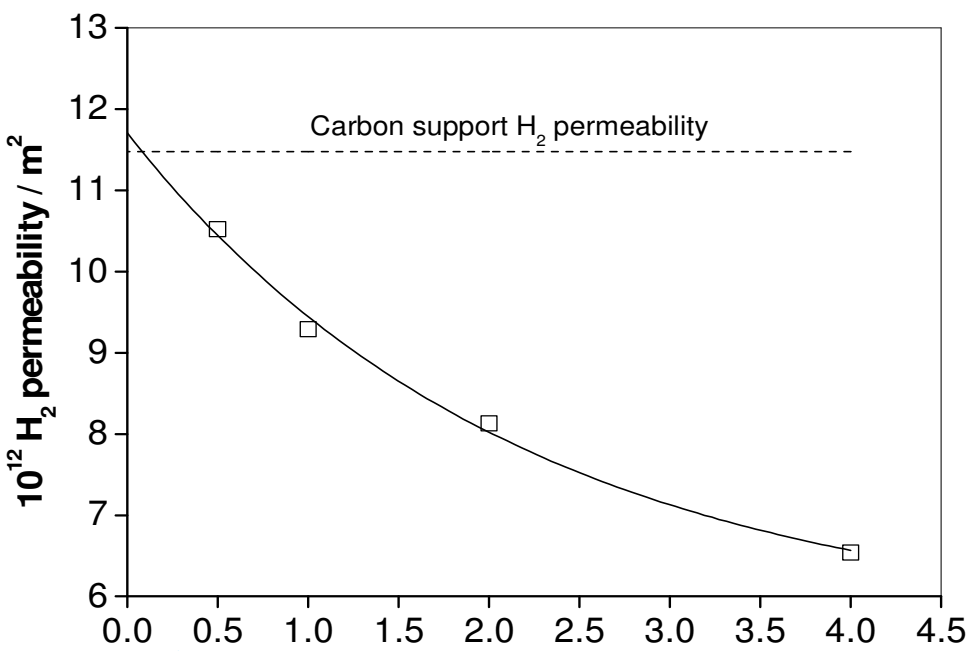

Carbon load on microporous layer $/ \mathrm{mg} \mathrm{cm}^{-2}$

(a)

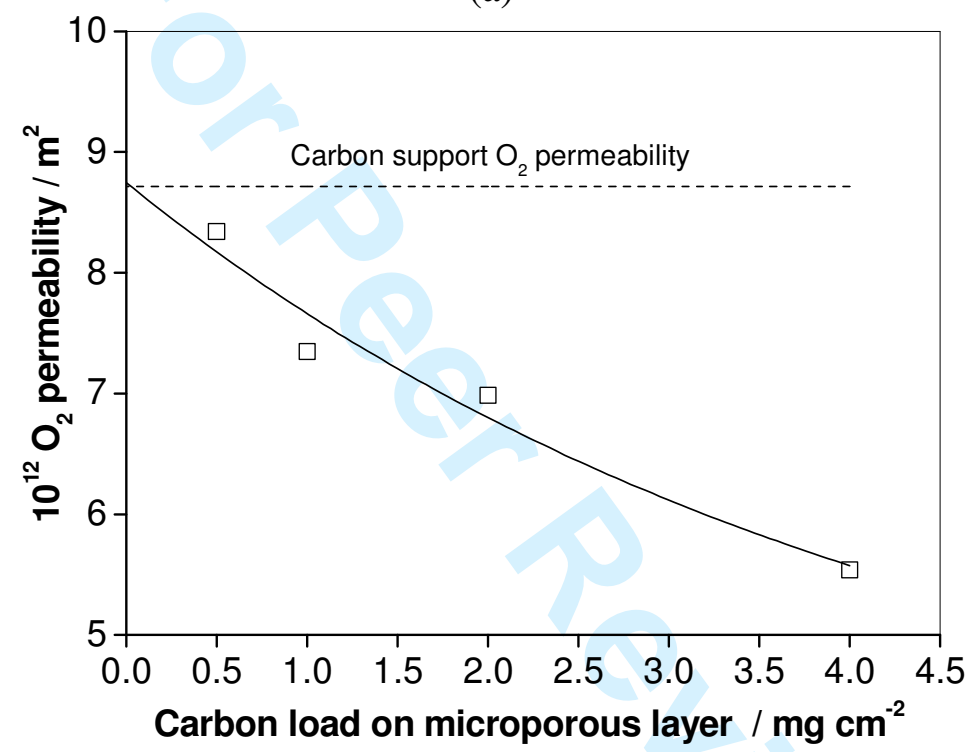

(b)

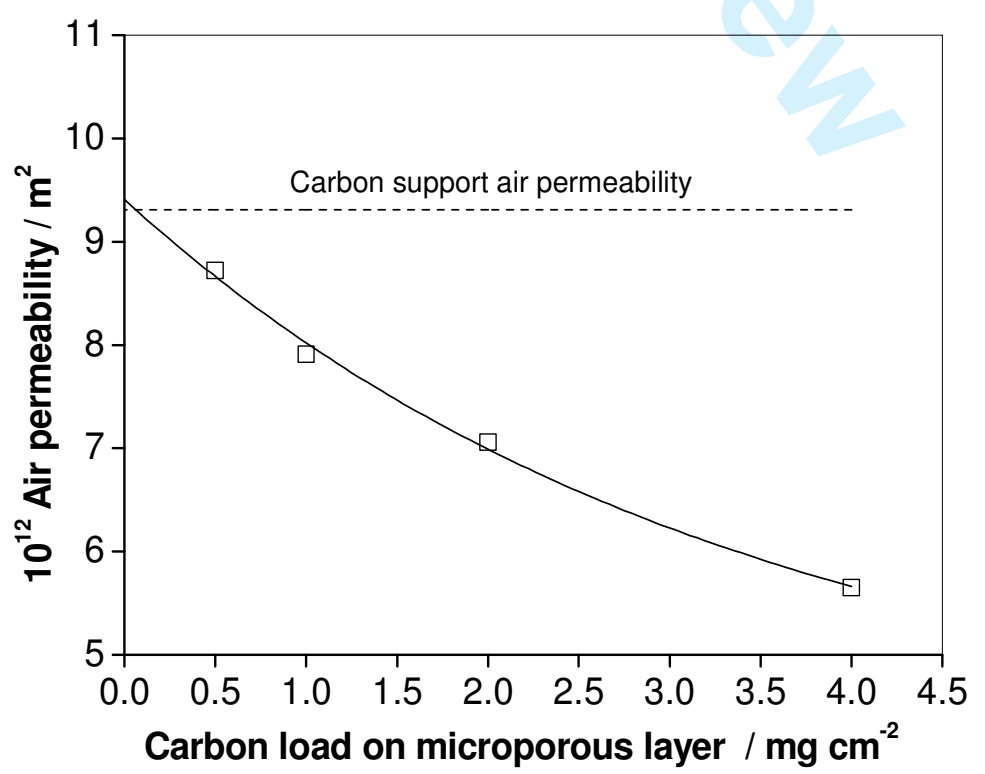

(c) 


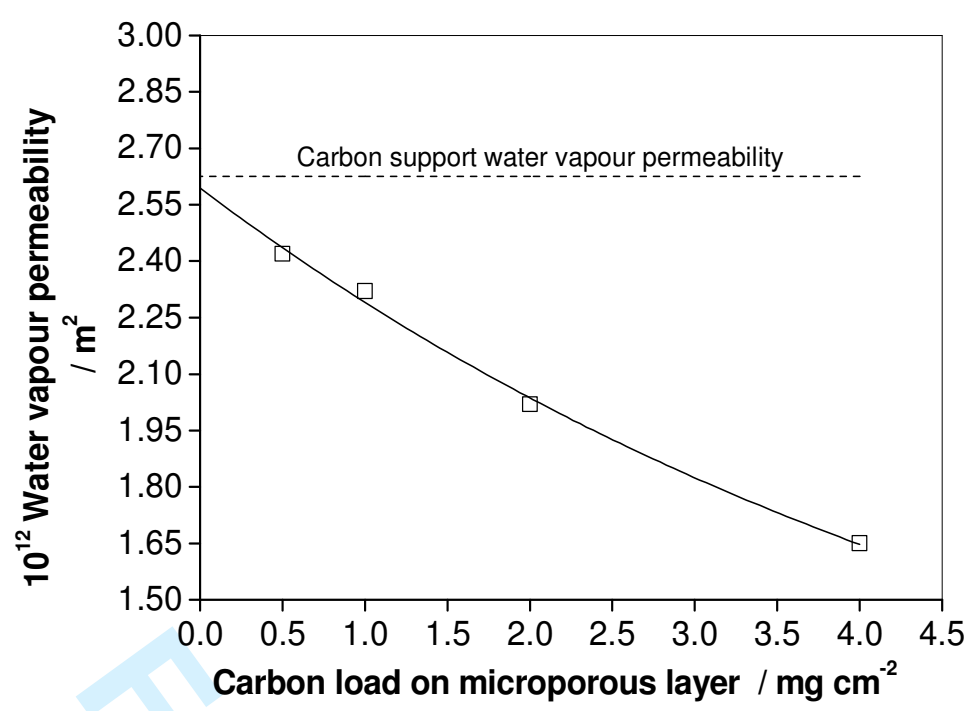

(d)

Figure 3 

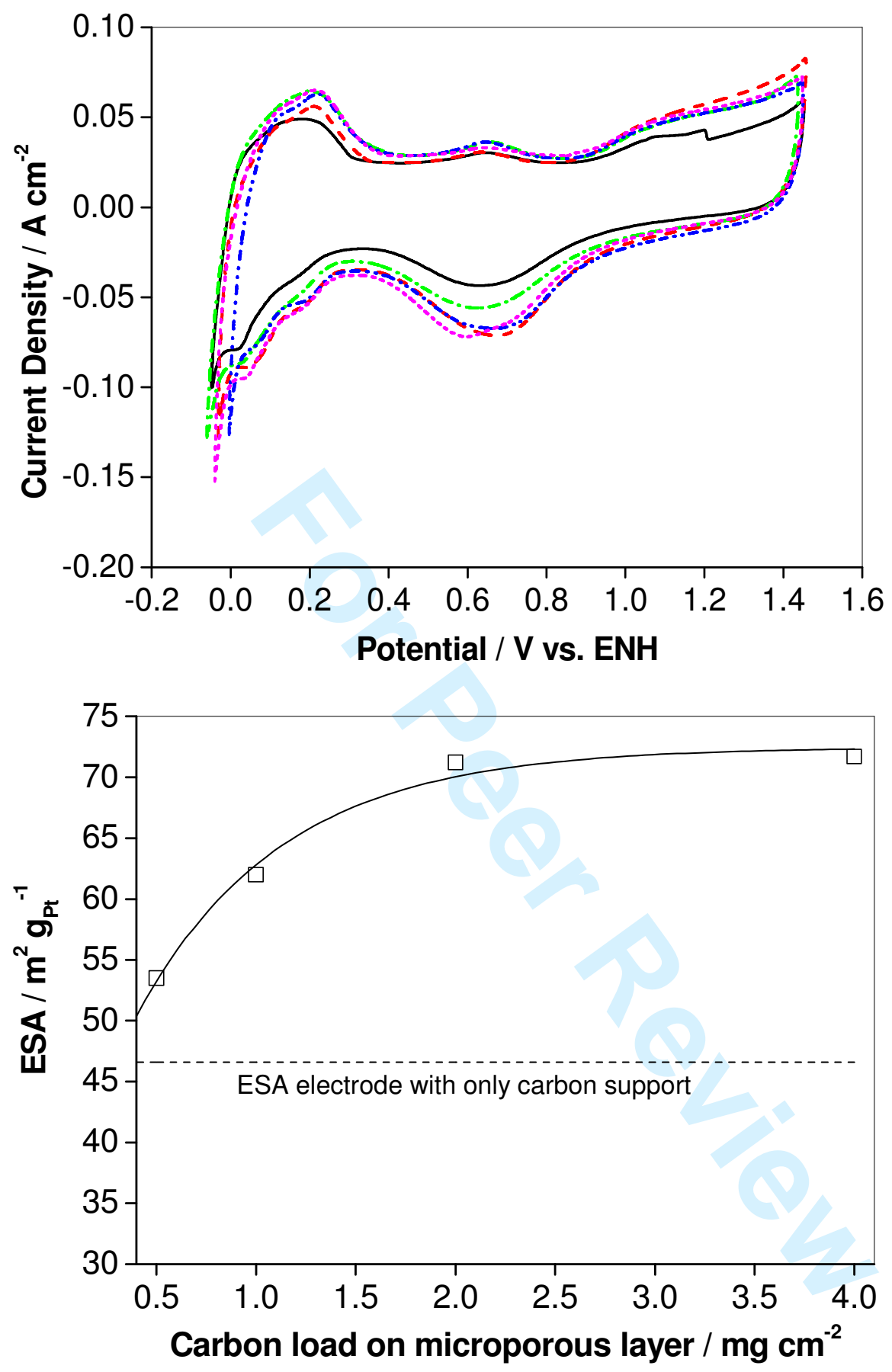

Figure 4 


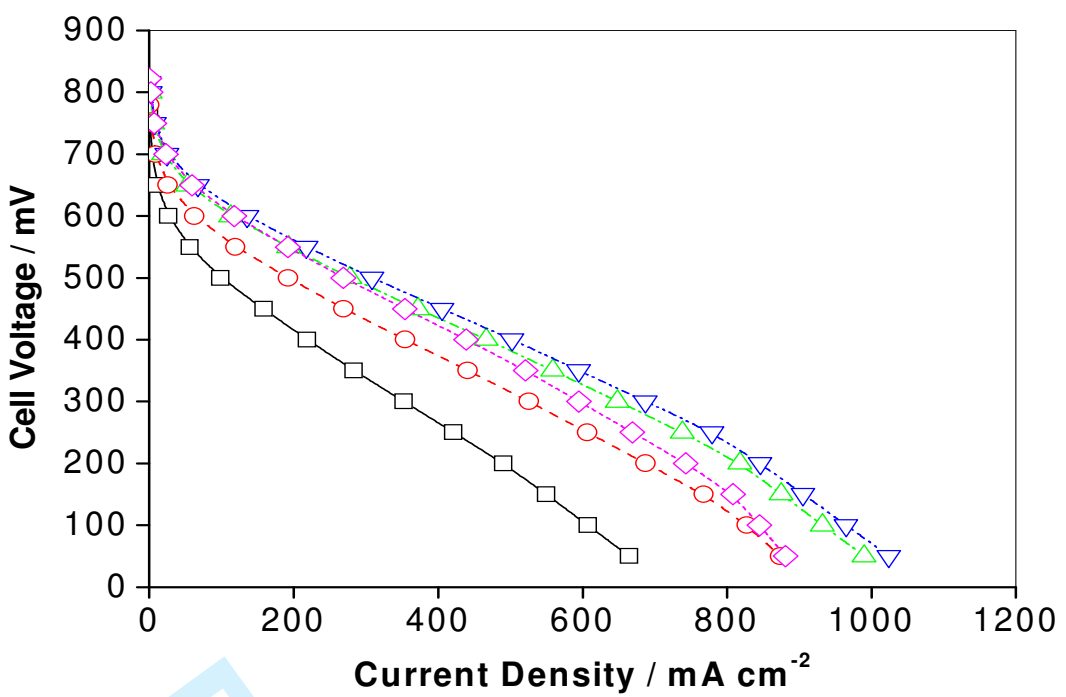

(a)

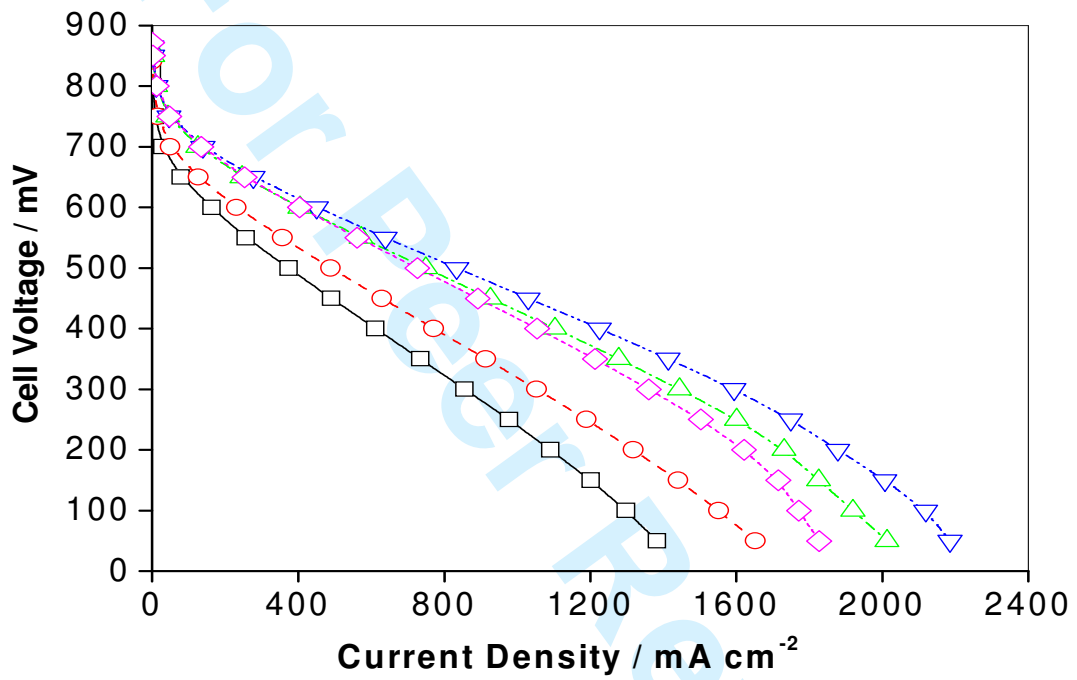

(b)

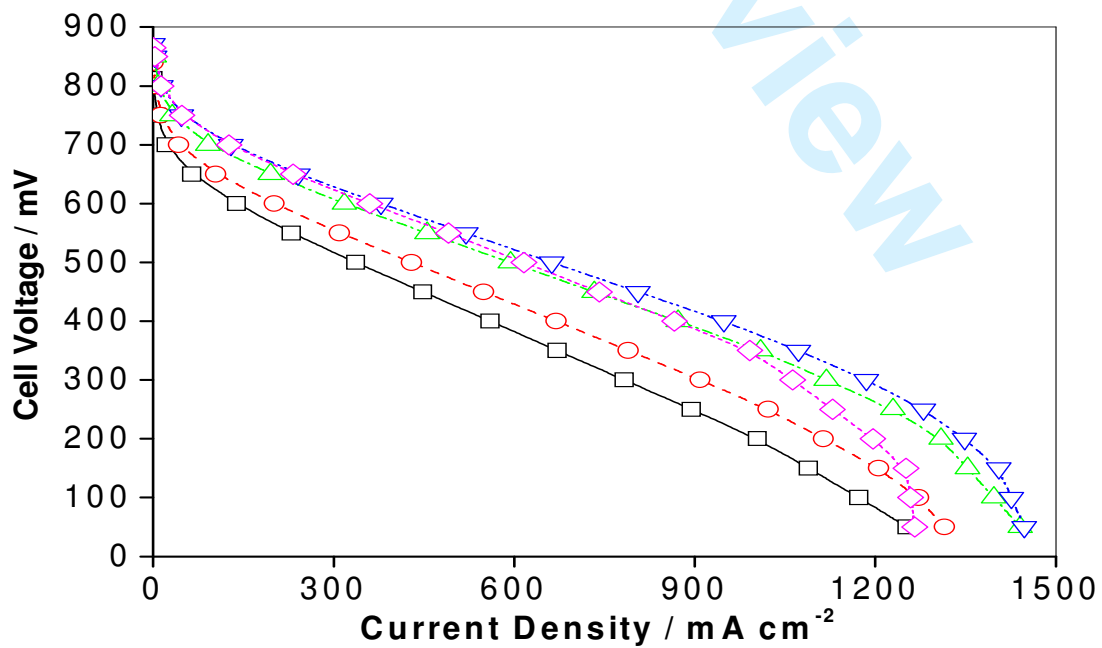

(c)

Figure 5 


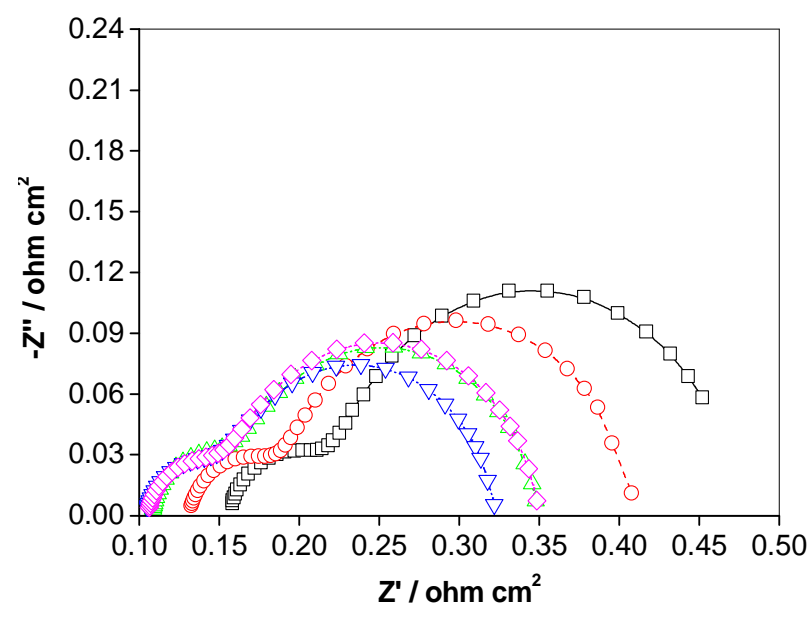

(a)

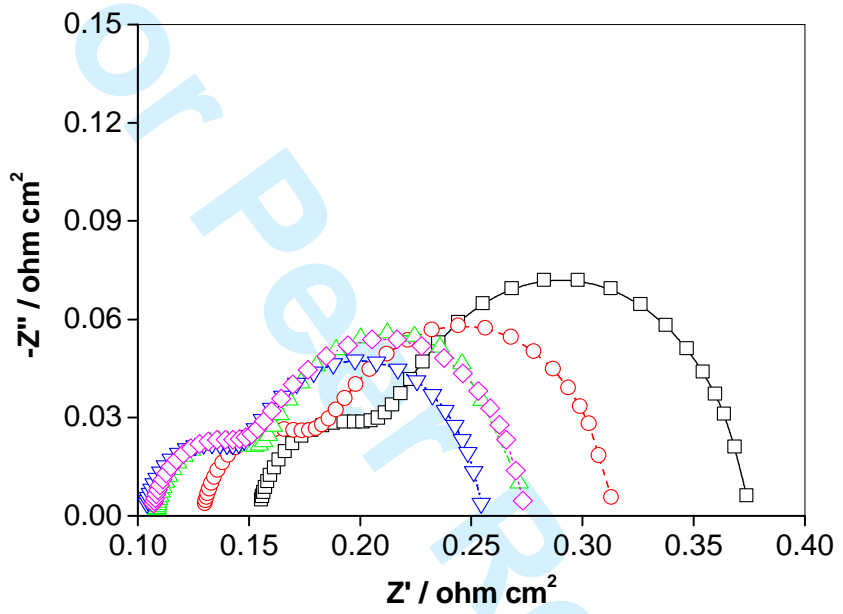

(b)

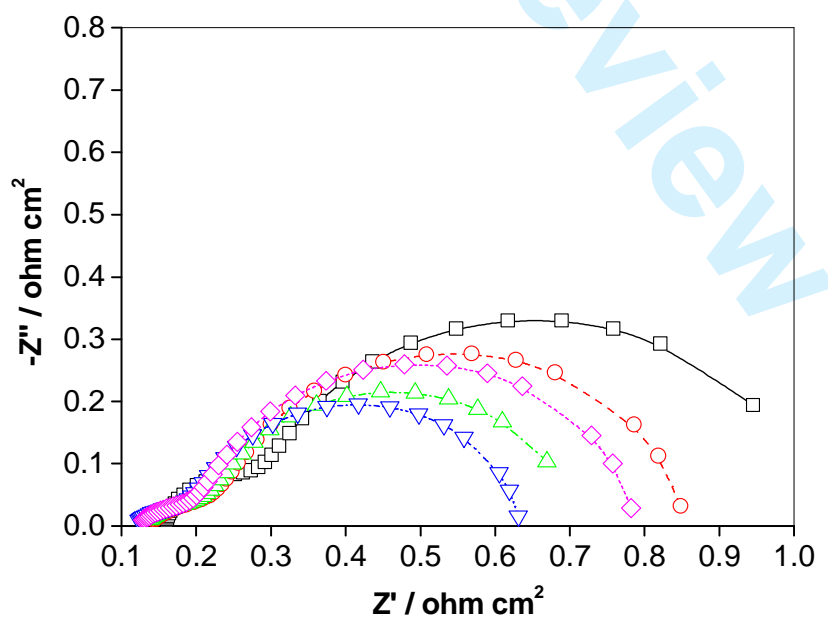

(c)

Figure 6 


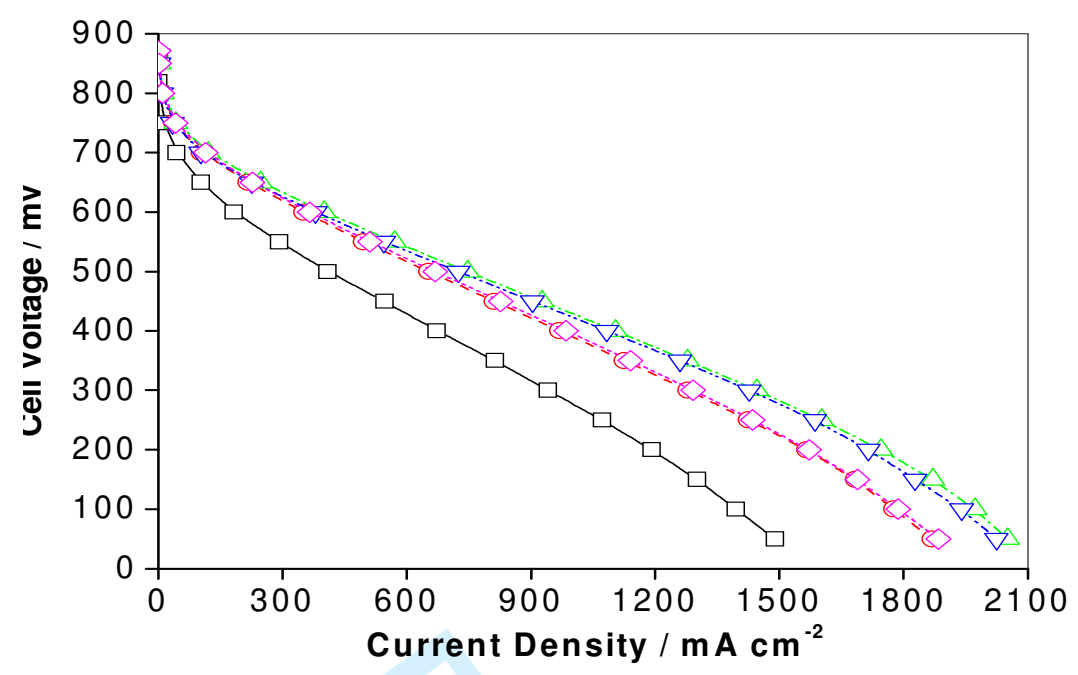

(a)

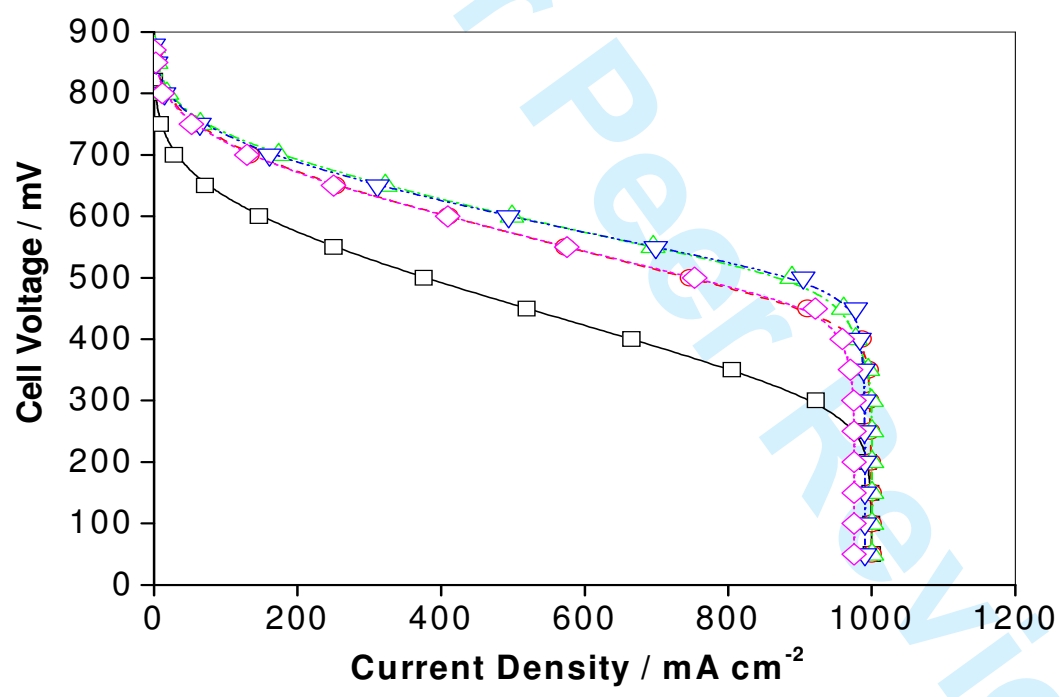

(b)

Figure 7 